\title{
Analisis Minat Belajar Siswa Kelas X SMA At-Taubah pada Materi SLPTV dengan Metode Pembelajaran Daring
}

\author{
Yulia Pratami Putri ${ }^{1}$, Alpha Galih Adirakasiwi² \\ ${ }^{1,2}$ Program Studi Pendidikan Matematika, Fakultas Keguruan dan Ilmu Pendidikan, Universitas Singaperbangsa Karawang, \\ Jl. HS. RonggoWaluyo, Puseurjaya, Kec. Telukjambe Timur, Kabupaten Karawang, Indonesia \\ pyuliatm@gmail.com
}

\begin{abstract}
This study aims to analyze the extent of interest in learning for high school students in class X MIPA 1 at AtTaubah Senior High School during the pandemic by using the online method on SPLTV material. This research is motivated by the low interest in student learning during online learning in previous studies. The method used in this research is descriptive qualitative method using a Likert scale. The instrument used in this study was a questionnaire consisting of positive and negative statements and amounted to 20 statements which aimed to measure students' interest during online learning on SPLTV material. The average result obtained is $76.39 \%$ with a strong category, so it can be said that the students of class X MIPA 1 at At-Taubah Senior High School have a good interest in learning mathematics in SPLTV material with the online method.
\end{abstract}

Keywords: interest in student learning, SPLTV, online method

\begin{abstract}
Abstrak
Penelitian bertujuan untuk menganalisis sejauh mana minat belajar siswa SMA kelas X MIPA 1 di SMA AtTaubah pada saat pandemi dengan menggunakan metode daring pada materi SPLTV. Penelitian ini dilatarbelakangi oleh rendahnya minat belajar siswa saat pembelajaran daring pada penelitian terdahulu. Metode yang digunakan pada penelitian ini adalah Metode Kualitatif Deskriptif menggunakan skala likert. Intrumen yang digunakan dalam penelitian ini berupa angket yang terdiri dari penyataan positif dan negatif dan berjumlah 20 penyataan yang bertujuan untuk mengukur minat siswa selama pembelajaran daring pada materi SPLTV. Diperoleh hasil rata-rata presentase 76,39\% dengan kategori kuat, maka dapat dikatakan siswa kelas X MIPA 1 di SMA At-Taubah memiliki minat belajar matematika yang baik pada materi SPLTV dengan metode daring.
\end{abstract}

Kata kunci: Minat Belajar, Materi Sistem Persamaan Linear Tiga Variabel (SPLTV), Pembelajaran Daring

Copyright (c) 2021 Yulia Pratami Putri, Alpha Galih Adirakasiwi

$\triangle$ Corresponding author: Yulia Pratami Putri

Email Address: pyuliatm@gmail.com (Jl. HS. RonggoWaluyo, Puseurjaya, Jawa Barat, Indonesia)

Received 12 Agustus 2021, Accepted 21 August 2021, Published 08 September 2021

\section{PENDAHULUAN}

Pendidikan merupakan suatu hak yang wajib dimiliki oleh peserta didik. Pendidikan memiliki tujuan tersendiri yaitu untuk membangun karakter serta pengetahuan tersendiri bagi peserta didik. Sehingga, dapat dikatakan bahwa pendidikan sangat memiliki tempat yang penting bagi peserta didik karena negara yang berkualitas ditandai denganadanya generasi penerus yang berkualitas. Menurut Undang-Undang Dasar Nomor 20 Tahun 2003 tentangpendidikan menyebutkan bahwa Pendidikan adalah usaha sadar dan terencana untuk mewujudkan suasana belajar dan proses pembelajaran agar peserta didik secara aktif mengembangkan potensi dirinya untuk memiliki kekuatan spiritual keagamaan, pengendalian diri, kepribadian, kecerdasan, akhlak mulia, serta keterampilan yang diperlukan dirinya,masyarakat, bangsa dan negara. Pengembangan potensi diri siswa dapat berupa kemampuan kognitif maupun afektif tentunya melalui pembelajaran. Pembelajaran merupakan suatu proseskegiatan belajar dengan guru sebagai fasilitator dan peserta didik sebagaisubjek untuk mencapai tujuan tertentu (Puteri \& Riwayati, 2017). Salah satu pembelajaran disekolah yang dirasa penting 
dipelajari oleh peserta didik adalah pembelajaran matematika.

Matematika merupakan ilmu yang sangat penting bagi dunia pendidikan maupun perkembangan teknologi.Matematika menjadi salah satu media pendidikan yang dapat berperan dalam mengembangkan generasi-generasiyang berkualitas. Menurut Kline (Rahmah, 2013) matematika itu bukanpengetahuan yang mandiri terutama dalam membangun dirinya sendiri, tetapi matematika itu memililiki fungsi tersendiri dalam membantu manusiadalam memahami dan mengatasipermasalahn sosial, ekonomi dan alam. Sehingga dapat dikatakan bahwamatematika juga ikut serta menyumbangkan perannya dalam bidang-bidang ilmu lain.

Matematika memiliki sifat abstrakdi dalam strukturnya. Menurut James dan James (Rahmah, 2013) matematika adalah suatu hubungan konsep, besaran, susunan yangdifikirkan secara logika Kemudian menurut Ruseffendi (Rahmah, 2013) matematika terorganisasikan dari unsur-unsur yang tidak didefinisikan, definisi-definisi, aksioma-aksioma, dan dalil- dalil di mana dalil-dalil setelah dibuktikan kebenarannya berlaku secaraumum, karena itulah matematika sering disebut ilmu deduktif. Berdasarkan beberapa pendapat para ahli tersebut dapat dikatakan bahwa matematika menekankan siswa dalam berfikir secaralogika untuk dapat memahami matematika. Selain itu, untuk mengefisienkan pembelajaran matematika perlu didampingi oleh kemampuan afektif yaitu minat belajar siswa.

Minat belajar merupakan suatu motivasi atau dorongan dalam diri sendiri yang tumbuh dari seseorang siswa atas keinginan sediri untuk meningkatkan kebiasaan belajar (Lestari, 2014). Menurut (Slameto, 2010) minat belajar adalah kecenderungan seseorang yang tetapuntuk mengenang serta memperhatikan beberapa kegiatan. Minat belajar yang diminati dapat menumbuhkan rasakepuasan tersendiri dan perasaansenang. Sehingga dapat disimpulkanbahwa minat belajar dapat menumbuhkan perhatian siswa dalam suatu kegiatan terutama dalam pembelajara dibarengi dengan perasaan senang yang tumbuh tanpa sebuah paksaan. Menurut (Djamarah, 2011) Indikator minat belajar siswa merupakan (1) perasaan senang, (2) ketertarikan siswa, (3) keterlibatansiswa, (4) rajin dan semangat mengerjakan tugas (5) tekun dan disiplin belajar.

Namun, dalam masa pandemi saat ini siswa dituntut untuk mengikuti kegaiatan belajar mengajar secara daring sehingga kemungkinan pembelajaran secara efisien dan bermakna tidak terelisiasi dengan baik, terutama dalam memahami materi sistem persamaan linear tiga variabel. Materi SPLTV menekankan pada konteks kehidupan sehari-hari dan pembelajaran bermakna sehingga diperlukan keaktifan siswa dalam bertanya maupun menumbuhkanperasaan senang dalam kegiatan pembelajaran, mengingat bahwa proses dalam menyelesaikan masalah pada materi ini cukup sulit. Dengan belajar secara daring siswa perlu berfikir ekstra untuk memahaminya dan mengurangi minatnya dalam belajar matematika.Hal ini sejalan dengan penelitian(Yunitasari \& Hanifah, 2020) bahwasanya pembelajaran daring membuat siswa mudah bosan karena pembelajaran daring tidak semenarik dengan suasana pembelajaran tatap muka.

Siswa yang memiliki minat belajar yang kurang akan menunjukan sikap bermain-main dalam belajar, tidak senang dalam berlatih materi yang diajarkan secara daring. Hal ini menunjukan perolehan 
hasil yang kurang memuaskan bagi hasil belajar siswa karena kendala jaringan, keterbatasan media, maupun kurangnya motivasi siswa dalam bertanya langsung kepada guru (April \& Dewi, 2021). Selain itu, managemant waktu juga menjadi salah satu fokus dalam pembelajaran daring. Optimalisasi pembelajaran sebelum masa pandemi dilakukan secara teratur dengan ketentuan tertentu dari sekolah, sedangkan pada masa pandemi saat ini siswa dituntun untuk mengatur waktu sendiri kapan ia akan mengikuti pembelajaran daring. Hal ini lah yang menyebabkan kurangnnya minat belajar siswa karena siswa seringkali lalai dalam me-manage waktu saat mengikuti pembelajaran daring (Sobron \& Meidawati, 2019).

Berdasarkan uraian tersebut peneliti tertarik untuk melakukan kajianulang mengenai minat belajar siswa saatpandemi, yang berjudul "Analisis MinatBelajar Siswa Kelas X SMA AT- TAUBAH Pada Materi SPLTV dengan Metode Belajar Daring" karena pada dasarnya pembelajaran secara daring memiliki keuntungan maupun kerugian tersendiri bagi siswa termasuk dalam pembelajaran matematika yang bersifat abstrak, sehingga perlunya pengkajian dalam minat belajar siswa pada masa pandemi saat ini.

\section{METODE}

Penelitian dilakukan pada SMA AT-TAUBAH penelitian dilakukan pada 26 siswa kelas X Mipa 1. Instrumen yang digunakan berupa angket tertutup dengan 20 pertanyaan. Metode yang digunakan dalam penelitian ini merupakan deskriptif dengan pendekatan kualitatif. Intrumen tes yang digunakan berupa angket tertutup dengan 20 pertanyaan. Pernyataan dibuat berdasarkan referensi (Rahmawati et al., 2015) untuk mengukur minat belajar siswa. Proses analisis dilaksanakan setelah siswa melaksanakan proses pembelajaran pada materi SPLTV secara daring.

Penskoran yang diberikan pada penelitian ini menggunakan skala likert yang terdiridari pernyataan positif dan negatif. Dalam menjawab angket, siswa diberikan opsi yang terdiri dari 4 skala yaitu Sangat Setuju (SS), Setuju (S), Tidak Setuju (TS), Sangat Tidak Setuju (STS). Adapun cara menambahkan skortersedia dalam Tabel 2 berikut:

Tabel 1. Pedoman Penskoran

\begin{tabular}{|l|c|c|}
\hline Respon siswa & Positif & Negatif \\
\hline Sangat Setuju (SS) & 4 & 1 \\
\hline Setuju (S) & 3 & 2 \\
\hline Tidak Setuju (TS) & 2 & 3 \\
\hline Sangat Tidak Setuju (STS) & 1 & 4 \\
\hline
\end{tabular}

Kemudian data diolah pada setiap indikator minat belajar siswa. Analisis data disesuaikan dengan indikator minat belajar siswa berdasarkan pendapat (Djamarah, 2011) yaitu (1) perasaan senang, (2) ketertarikan siswa, (3) keterlibatan siswa, (4) rajin dan semangat mengerjakan tugas (5) tekun dan disiplin belajar.

Analisis data yang dilakukan disesuaikan dengan pendapat (Sugiyono, 2011) yaitu angket yang 
telah disebarkan dikumpulkan hasil datanya untuk diolah. Kemudian data diolah (reduksi) agar dapat digunakan sebagai jawaban penelitian. Selanjutnya hasil pengolahan data perindikator dikategorikan berdasarkan skala interpretasi presentase minat belajar menurut (Riduwan, 2015) dan disajikan dalam bentuk tabel skala intrepertasi skor perhitungan dalam bentuk dalam presentase, sebagai informasi yang didapatkan dari penelitian. Berikut ini adalah tabel skala interpretasi minat belajar:

Tabel 2. Skala Interpretasi Minat Belajar

\begin{tabular}{|c|c|}
\hline Presentase & Kategori \\
\hline $0-20 \%$ & Sangat Lemah \\
\hline $21-40 \%$ & Lemah \\
\hline $41-60 \%$ & Cukup \\
\hline $61 \%-80 \%$ & Kuat \\
\hline $81 \%-100 \%$ & Sangat Kuat \\
\hline
\end{tabular}

\section{HASIL DAN DISKUSI}

Pemberian instrumen minat belajar siswa disesuaikan dengan rujukan (Rahmawati et al., 2015) Hasil pengolahan data akan merujuk pada kategori minat siswa terhadap pembelajaran matematika secara daring pada materi SPLTV selama pembelajaran daring. Pelaksanaan pembelajaran daring dilakukan menggunakan media E-learning dan Whatsapp. Angket minat belajar diisi setelah melakukan kegiatan pembelajaran yang dilaksanakan bersama guru. Hasil perhitungan secara menyeluruh dipresentasekan dalam tabel interpretasi minat belajar sebagai berikut:

Tabel 3. Interpretasi Presentase Minat Belajar Siswa

\begin{tabular}{|c|c|c|c|c|}
\hline Indikator & Total Skor & Rata-rata & $(\%)$ & Kategori \\
\hline Perasaan senang & 224 & 74,67 & $71,79 \%$ & Kuat \\
\hline Ketertarikan siswa & 508 & 169,3 & $69,78 \%$ & Kuat \\
\hline Keterlibatan siswa & 242 & 80,67 & $77,56 \%$ & Kuat \\
\hline Rajin dan bersemangat & 250 & 83,33 & $80,15 \%$ & Sangat Kuat \\
\hline Tekun dan disiplin & 334 & 86,00 & $82,69 \%$ & Sangat Kuat \\
\hline \multicolumn{3}{|c|}{ Rata-rata } & $79,39 \%$ & Kuat \\
\hline
\end{tabular}

Berdasarkan data yang diperoleh pada tabel 3 dapat dilihat bahwa pada indikator pertama yaitu perasaan senang memiliki presentase $71,79 \%$ dan berada pada kategori kuat yang berarti siswa memiliki perasaan senang saat belajar materi SPLTV dengan metode daring. Kemudian, pada indikator ketertarikan siswa hasil analisis menunjukan bahwa siswa berada pada kategori kuat dengan presentase $69,78 \%$, hal ini berarti metode pembelajaran daring memiliki ketertarikan yang cukup bagi siswa untuk melakukan kegiatan belajar mengajar. Pada kategori keterlibatan siswa diperoleh presentase 77,56\% dengan ketegori kuat, hal ini menunjukan bahwa siswa selalu bergabung dan mengikuti setiap proses pembelajaran daring terutama dalam materi SPLTV. Pada kategori rajin dan bersemangat siswa berada pada kategori sangat kuat dengan presentase $80,15 \%$, hal ini menunjukan bahwa siswa sangat sering mengikuti kegiatan belajar mengajar dan mengumpulkan tugas pada materi SPLTV. Pad indikator tekun dan disiplin siswa berada pada kategori sangat kuat dengan presentase $82,69 \%$, hal ini menunjukan 
bahwa siswa sangat disiplin saat belajar menggunakan metode daring terutama dalam mempelajari materi SPLTV, sehingga kegiatan pembelajaran dapat terkondisikan secara optimal.

Minat belajar merupakan salah satu aspek dalam diri siswa yang dapat tumbuh untuk memotivasi siswa itu sendiri saat melakukan keinginannya dalam kegiatan belajar mengajar. Berdasarkan hasil analisis secara keseluruhan menunjukan bahwa siswa memiliki minat belajar yang baik dengan rata-rata presentase 79,39\% sehingga motivasi siswa melakukan kegiatan beajar mengajar disaat pandemi dikatakan baik. Hal ini sejalan dengan pendapat Hansen (Fauziah et al., 2017) bahwa minat belajar siswa sangat berpengaruh kepada motivasi, konsep diri, kepribadian siswa. Minat belajar akan mengoptimalkan hasil belajar dan akan menjembatani konsep diri siswa dalam proses belajar selanjutnya (Slameto, 2003).

Pada indikator pertama yaitu perasaan senang, siswa mampu belajar dengan metode daring tanpa paksaan sehingga kegiatan belajar mengajar terjadi secara sukarela. Proses pembelajaran dengan perasaan senang pada siswa akan mudah terelisiasi dan mengkontruksi siswa secara natural tanpa terbebani. Menurut (Slameto, 2010) siswa yang tidak terbebani dalam kegiatan belajar mengajar akan turut aktif dalam berpartisipasi pada kegiatan belajar sehingga pencapaiannya akan baik.

Pada indikator kedua yaitu ketertarikan, siswa memiliki keinginan untuk belajar secara daring. Media belajar seperti video maupun aplikasi yang sering kali digunakan saat penyampaian materi SPLTV oleh guru menjadi pusat perhatian bagi siswa itu sendiri. Menurut Rusyan (Supriyono, 2018) prinsip media belajar adalah digunakan sebagai alat komunikasi yang baik dan cukup efisien terutama dalam proses pembelajaran daring saat ini sehingga menumbuhkan minat belajar pada siswa.

Pada indikator ketiga yaitu keterlibatan siswa, terlihat bahwa siswa berada pada kategori kuat yang berarti siswa selalu berpartisipasi untuk mengikuti pembelajaran, bertanya jika kurang memahami dan mengumpulkan tugas secara daring. Hal ini sejalan dengan penelitian (Mustika \& Kusdiyati, 2015) bahwasanya siswa yang memiliki rasa keterlibatan yang tinggi dalam belajar akan terus berusaha dengan giat dan selalu mengikuti pembelajaran dengan baik di dalam maupun diluar sekolah secara tekun. Hal ini sangat menunjang siswa untuk meningkatkan pemahamannya dalam belajar SPLTV secara daring.

Pada indikator keempat yaitu rajin dan bersemangat, menunjukan bahwa siswa berada pada kategori sangat kuat yang mana siswa sangat termotivasi untuk giat dalam mempelajari materi SPLTV secara daring. Berdasarkan hasil wawancara beberapa siswa, diungkapkan bahwa siswa bersemangat dalam memahami materi SPLTV secara daring karena akses sumber belajar yang tidak terbatas memudahkan siswa untuk belajar maupun mengerjakan tugas. Menurut Hamalik (Rohmawati, 2015) suatu pembelajaran dapat dikatakan efektif jika kegiatan pembelajaran memberikan kesempatan kepada siswa untuk belajar sendiri dan mengayomi siswa untuk beraktivitas seluas-luasnya guna memperluas pengetahuan siswa dalam belajar. Sehingga, kegiatan pemahaman materi SPLTV ini kurang lebih banyak melibatkan kehidupan sehari-hari dan siswa dapat mempelajarinya dengan memanfaatkan pembelajaran dirumah dan mengeksplor pengetahuan sebanyaknya dengan internet. Hal ini lah yang 
membuat siswa lebih bersemangat dan rajin dalam mengikuti kegiatan belajar.

Pada indikator kelima yaitu tekun dan disiplin, diperoleh hasil kategori sangat kuat yang menunjukan bahwa siswa mampu untuk belajar bersungguh-sungguh. Menurut Sumantri (Tamardiyah, 2017) kedisiplinan tidak mengurangi kemerdekaan siswa. Dalam memulakan suatu kedisplinan tentunya diawali oleh beberapa aturan tetapi lama kelamaan akan menjadi sebuah kebiasaan yang secara sadar dirasakan oleh siswa. Sehingga, siswa yang disiplin akan menerapkan keteraturan dalam kegiatan belajar daring, mengikuti pembelajaran daring tepat waktu dan fokus dalam mengikuti kegiatan belajar mengajar secara daring. Siswa yang memiliki kedisiplinan tidak memerangi peraturan sebagai beban melainkan sebagai pemicu dirinya untuk mengetahui sejauhmana kemampuannya.

\section{KESIMPULAN}

Berdasarkan hasil penelitian diperoleh minat belajar siswa yang baik dengan rata-rata presentase 79,39\% dengan kategori kuat. Hal ini menunjukan siswa kelas X SMA At- Taubah memiliki minat belajar matematika yang baik dalam mempelajari materiSPLTV menggunakan metode daring. Selain ini indikator (4) Rajin dan bersemangat serta indikator (5) disiplin dan tekun belajar memimiliki presentase tertinggi pada kategori sangat kuat dengan nilai secara berturut-turut adalah $80,13 \%$ dan $82,69 \%$. Hal ini juga menunjukan bahwa siswa SMA AT-TAUBAH giat mengikuti kegiatan pada pembelajaran daring serta mengikuti aturan selama pembelajaran daring tentunya fokus dan tekun dalam mempelajari materi SPLTV.

\section{REFERENSI}

April, B., \& Dewi, R. P. (2021). Minat Siswa SMP Terhadap Pembelajaran PJOK Secara Daring Pada Masa New Normal Junior High School Students Interest in Online Physical Education Learning During the New Normal Period. 2(April).

Djamarah, S. B. (2011). Psikologi Belajar. Jakarta: PT. Rineka Cipta.

Fauziah, A., Rosnaningsih, A., \& Azhar, S. (2017). Hubungan Antara Motivasi Belajar Dengan Minat Belajar Siswa Kelas IV SDN Poris Gaga 05 Kota Tangerang. JURNAL JPSD (Jurnal Pendidikan Sekolah Dasar), 4(1), 48-53. https://doi.org/10.26555/jpsd.v4i1.a9594

Lestari, I. (2014). Pengaruh Waktu Belajar Dan Minat Belajar. Jurnal Formatif, 3(2), 115-125.

Mustika, R. A., \& Kusdiyati, S. (2015). Studi Deskriptif Student Engagement pada Siswa Kelas XI IPS di SMA Pasundan 1 Bandung. 244-251.

Puteri, W. J., \& Riwayati, S. (2017). Kemampuan Koneksi Matematis Siswa pada Model Pembelajaran Conneted Mathematics Project (CMP). Jurnal Pendidikan Matematika Dan Matematika, 3(2), $161-168$.

Rahmah, N. (2013). Hakikat Pendidikan Matematika. Al-Khwarizmi: Jurnal Pendidikan Matematika 
Dan Ilmu Pengetahuan Alam, 1(2), 1-10. https://doi.org/10.24256/jpmipa.v1i2.88

Rahmawati, N. S., Bungsu, T. K., Islamiah, I. D., \& Setiawan, W. (2015). Analisis Minat Belajar Siswa MA Al-Mubarok Melalui Pendekatan Saintifik Berbantuan Aplikasi Geogebra Pada Materi Statistika Dasar. Journal On Education, 01(03), 386-395.

Riduwan. (2015). Dasar-Dasar Statistika. Bandung: Alfabeta.

Rohmawati, A. (2015). Efektivitas Pembelajaran. Jurnal Pendidikan Usia Dini, 9(1), 15-32. https://doi.org/https://doi.org/10.21009/JPUD.091

Slameto. (2003). Belajar dan Faktor-faktor yang mempengaruhinya. Jakarta: Rineka Cipta.

Slameto. (2010). Belajar dan faktor-faktor yang Mempengaruhinya. Jakarta: PT. Rineka Cipta.

Sobron, A. N., \& Meidawati, S. (2019). Persepsi Siswa Dalam Studi Pengaruh Daring Learning Terhadao Minat Belajar IPA. 1(2), 30-38.

Sugiyono. (2011). Metode Penelitian Kombinasi. Bangung : PT. Alpha Beta.

Supriyono. (2018). Pentingnya Media Pembelajaran Untuk Meningkatkan Minat Belajar Siswa SD. Edustream: Jurnal Pendidikan Dasar, 2(1), 43-48.

Tamardiyah, N. D. (2017). Minat kedisiplinan dan ketekunan belajar terhadap motivasi berprestasi dan dampaknya pada hasil belajar matematika smp. Jurnal Manajemen Pendidikan, 12(1), 26-37.

Yunitasari, R., \& Hanifah, U. (2020). Pengaruh Pembelajaran Daring terhadap Minat Belajar Siswa pada Masa COVID 19. Edukatif: Jurnal Ilmu Pendidikan, 2(3), 236-240. https://doi.org/10.31004/edukatif.v2i3.142. 